\title{
Pencegahan Penularan Covid-19 melalui Pembagian Masker dan Desain Infografis di Pasar Badung, Denpasar-Bali
}

\author{
Made Arini Hanindharputri ${ }^{1}$, A.A Sagung Intan Pradnyanita ${ }^{2}$, Sri Utami ${ }^{3}$ \\ ${ }^{1,2}$ Desain Komunikasi Visual, Institut Desain dan Bisnis Bali, Denpasar, Bali \\ ${ }^{3}$ Desain Mode, Institut Desain dan Bisnis Bali, Denpasar, Bali
}

\section{Article history}

Received: 30-12-2020

Revised: 18-03-2021

Accepted: 19-06-2021

*Corresponding Author:

Made Arini

Hanindharputri,

Desain Komunikasi Visual, Institut Desain dan Bisnis

Bali, Denpasar, Indonesia;

Email:

arini@idbbali.ac.id.
Abstract: The COVID-19 pandemic, which has hit almost all countries in the world, requires all people to comply with health protocols to face new life, such as using masks in everyday life. In Denpasar, Bali itself, the number of COVID-19 transmissions continues to increase, so masks are mandatory items that must be owned by the community. However, conditions in the field, there are still many people who do not use masks in their daily activities, such as at Badung Market, Denpasar. The market as a place of buying and selling that involves the interaction of many people, should have more health protocols so that it does not become a new cluster in the spread of COVID-19. Therefore, community service was made by involving lecturers and students of all Study Programs at the Bali Design and Business Institute, in the form of distributing cloth masks and infographics to provide education to the public, especially traders and the community in the Badung Market area, Denpasar-Bali. The methods used are choosing the location for distributing masks, collecting cloth materials for mask production, producing masks, designing infographics and mask packaging, packaging, and distributing masks in the Badung Market area. The resulting cloth masks are packaged together with infographics, so that people can easily get education on preventing COVID-19 by using masks.

Keywords: Prevention of COVID-19 Transmission; distribution of masks; infographic design

Abtrak: Pandemi COVID-19 yang melanda hampir seluruh negara di dunia, mewajibkan seluruh masyarakat untuk mematuhi protokol kesehatan untuk menghadapi kehidupan baru seperti menggunakan masker dalam kehidupan seharihari. Di Denpasar, Bali sendiri, angka penularan COVID-19 terus mengalami peningkatan, sehingga masker menjadi barang wajib yang harus dimiliki oleh masyarakat. Namun kondisi di lapangan, masih banyak masyarakat yang tidak menggunakan masker dalam aktivitas sehari-hari, seperti di Pasar Badung, Denpasar. Pasar sebagai tempat jual beli yang melibatkan interaksi banyak orang, seharusnya memiliki protocol kesehatan yang lebih sehingga tidak menjadi klister baru dalam penyebaran COVID-19. Oleh karena itu dibuatlah pengabdian kepada masyarakat dengan melibatkan dosen dan mahasiswa seluruh Program Studi yang ada di Institut Desain dan Bisnis Bali, berupa pembagian masker kain dan infografis untuk memberikan edukasi kepada masyarakat, khususnya pedagang dan masyarakat di areal Pasar Badung, Denpasar-Bali. Metode yang dilakukan adalah pemilihan lokasi penyebaran masker, pengumpulan bahan kain untuk produksi masker, produksi masker, perancangan infografis dan kemasan masker, pengemasan, dan distribusi masker di areal Pasar Badung. Masker kain yang dihasilkan, dikemas bersamaan engan infografis, sehingga masyarakat dapat dengan mudah mendapatkan edukasi pencegahan COVID-19 dengan menggunakan masker.

Kata Kunci: Pencegahan Penularan COVID-19; pembagian masker; desain infografis 


\section{PENDAHULUAN}

Virus Corona atau Covid-19 (Corona Virus Disease 2019) merupakan virus yang menyerang sistem pernafasan dan sudah menjadi pandemi yang melanda hampir seluruh negara di dunia. Sejak mewabahnya virus COVID-19 yang merenggut ribuan korban, kesehatan menjadi sorotan utama di masyarakat. Virus yang dapat mematikan ini, pertama kali ditemukan di kota Wuhan, Cina pada akhir Desember 2019 dan secara cepat menyebar. Di Indonesia sendiri, termasuk di Bali, penyebaran virus Covid-19 juga sangat masif sejak bulan Maret 2020. Menurut data yang dirilis Gugus Tugas Percepatan Penanganan COVID-19 Republik Indonesia, jumlah kasus terkonfirmasi positif hingga 23 November 2020 adalah 497.668 orang dengan jumlah kematian 15.884 orang. Tingkat kematian (case fatality rate) akibat COVID-19 adalah sekitar 3,2\% (Pane. 2020). Sedangkan di Bali, khususnya di Denpasar, angka penularan Covid-19 terus mengalami peningkatan. Dengan diberlakukan adaptasi kebiasaan baru bagi masyarakat di Indonesia, pemerintah mewajibkan masyarakat untuk mematuhi protokol kesehatan, seperti penggunaan masker dalam kehidupan sehari - hari. Menurut WHO, penggunaan masker dapat menghambat terjadinya penularan virus Covid-19 baik melalui droplet dari orang yang terinfeksi atau pun dari udara atau airborne (WHO. 2020).

Melihat penyebaran virus COVID-19 yang semakin meningkat, seharusnya masyarakat mematuhi standar protokol kesehatan yang dianjurkan oleh pemerintah. Namun melihat kondisi di lapangan, masih banyak masyarakat yang tidak menggunakan masker dalam aktivitas sehari-hari ketika berada di luar rumah. Masyarakat masih merasa abai dan tidak disiplin untuk mengenakan masker, padahal Pemerintah Provinsi Bali sudah mengeluarkan Peraturan Gubernur Bali Nomor 46 Tahun 2020 tentang Penerapan Disiplin dan Penegakan Hukum Protokol Kesehatan sebagai Upaya Pencegahan dan Pengendalian Corona Virus Disease 2019 dalam Tatanan Kehidupan Baru yang menetapkan denda sebesar Rp 100.000,- bagi individu dan denda administratif sebesar Rp 1.000.000,bagi pelaku usaha, penyelenggara, pengelola atau penanggung jawab tempat atau fasilitas umum yang tidak mematuhi protokol kesehatan, termasuk dalam penggunaan masker (Peraturan Gubernur Provinsi Bali. 2020). Salah satu fasilitas umum yang sangat sering dikunjungi oleh masyarakat di Denpasar, adalah Pasar Badung. Pasar Badung sebagai tempat transaksi jual beli yang melibatkan interaksi banyak orang, seharusnya memiliki protokol kesehatan yang lebih sehingga tidak menjadi klaster baru dalam penyebaran COVID-19. Namun kenyataannya, masih banyak pedagang dan pengunjung pasar yang tidak menggunakan masker dalam kegiatan sosial yang mereka jalankan di areal pasar.

Oleh karena itu dibuatlah pengabdian kepada masyarakat dengan melibatkan dosen dan mahasiswa seluruh Program Studi yang ada di Institut Desain dan Bisnis Bali, berupa pembagian masker kain dan infografis untuk memberikan edukasi kepada masyarakat tentang pentingnya mematuhi protokol kesehatan, khususnya pedagang dan masyarakat di areal Pasar Badung, DenpasarBali.

\section{METODE}

Kegiatan pengabdian kepada masyarakat ini diselenggarakan oleh Institut Desain dan Bisnis Bali dengan melibatkan dosen dan mahasiswa dari tiga program studi yaitu Desain Komunikasi Visual, Desain Mode dan Desain Interior. Melihat permasalahan yang terjadi di lapangan, masyarakat Denpasar di areal Pasar Badung masih mengabaikan penggunaan masker sehingga diperlukan pengabdian kepada masyarakat yang tidak hanya memberikan masker kain secara cuma-cuma kepada pedagang dan pengunjung di areal pasar Badung, tetapi juga memberikan edukasi berupa informasi 
dalam bentuk infografis. Masker kain yang dibagikan juga merupakan masker hasil karya dari dosen dan mahasiswa Desain Mode, Institut Desain dan Bisnis Bali.

Adapun metode yang dilakukan untuk menyelesaikan permasalahan adalah:

1. Pemilihan lokasi penyebaran masker dengan melihat skala prioritas dan pencegahan klaster baru penyebaran virus COVID-19, yaitu di pasar Badung

2. Pencarian bahan untuk memproduksi masker kain

3. Pelaksanaan produksi masker

4. Proses mendesain kemasan masker, infografis untuk dicetak sesuai jumlah masker yang akan dibagikan

5. Distribusi atau pembagian masker di areal Pasar Badung yang diadakan pada tanggal 26 April 2020.

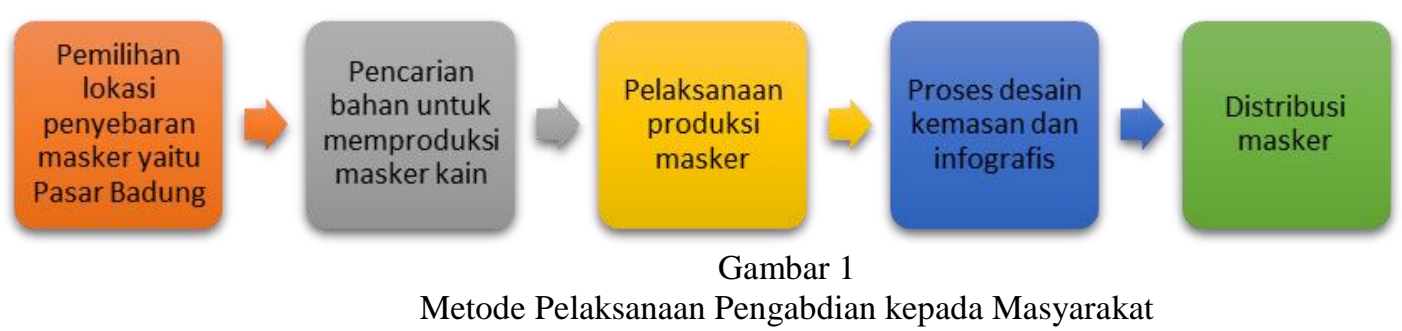

Pasar Badung merupakan pasar rakyat di kota Denpasar yang beroperasi selama 24 jam dan telah menjadi pusat perekonomian masyarakat kota Denpasar sejak zaman kerajaan dahulu. Selain menjual berbagai kebutuhan rumah tangga sehari - hari, pasar ini juga menjual kebutuhan upacara dan memiliki daya tarik wisatawan mancanegara karena berlokasi di Kawasan Heritage yang masih mempertahankan budaya dan arsitektur tradisional Bali (Dinas Pariwisata Denpasar. 2020). Pasar ini terbagi menjadi empat lantai dan memiliki luas $8.016 \mathrm{~m}^{2}$. Dengan besarnya luas dan banyaknya kios di dalam pasar serta jam operasional yang 24 jam, tentu pasar Badung menjadi pilihan masyarakat untuk berbelanja barang-barang kebutuhan sehari-hari bahkan di saat pandemi saat ini. Namun, dalam kenyataannya masih banyak pedagang maupun pengunjung pasar yang masih abai menerapkan protokol Kesehatan yang paling sederhana, yaitu mengenakan masker kain ketika keluar rumah.

\section{HASIL DAN PEMBAHASAN}

Proses pengabdian kepada masyarakat ini berlangsung sejak awal bulan April 2020 hingga awal bulan Mei 2020 dengan beberapa langkah yaitu:

1. Langkah pertama, yaitu proses produksi masker kain. Tim produksi masker kain yang terdiri dari dosen dan mahasiswa semester 2 program studi Desain Mode mengawali kegiatan dengan pembelian bahan baku yaitu kain rayon dengan biru dan oranye. Warna ini merupakan warna identitas dari kampus Institut Desain dan Bisnis Bali. Kegiatan produksi tersebut dilakukan secara terpisah yaitu di lab fashion milik Institut Desain dan Bisnis Bali dan di rumah masing - masing. Hal ini dikarenakan jumlah mesin jahit di lab fashion yang terbatas dan diberlakukannya protokol kesehatan yang mewajibkan civitas akademika untuk melakukan physical distancing termasuk di dalam ruang kelas. Gambar 1 Proses Produksi Masker Kain

2. Langkah kedua, tim desain yang terdiri dari dosen Desain Komunikasi Visual Institut Desain dan Bisnis Bali melakukan perancangan kemasan dan infografis sebagai bahan edukasi penyebaran masker kain kepada masyarakat. Kemasan ini berfungsi sebagai pelindung masker kain yang ada di dalamnya, dan sebagai sarana komunikasi produk dan branding kepada konsumen. Menurut Julianti (2014:15), kemasan dapat menjadi pelindung kualitas produk yang ada di dalamnya, sehingga konsumen yang mendapatkan produk tersebut juga merasa aman dan bersih ketika mendapatkan produk tersebut. Terlebih lagi, produk yang akan dibagikan secara masal ini merupakan masker kain yang akan dipakai sebagai alat menangkal virus, maka masyarakat harus 
merasa mendapatkan masker kain yang bersih dan baru. Kemasan yang dirancang berukuran A4 $(27,7 \mathrm{~cm} \times 21 \mathrm{~cm})$ yang dapat dilipat untuk memudahkan memasukkan masker kain dan juga infografis. Untuk memberikan pemahaman mengenai protokol Kesehatan dan cara mencuci masker kain, dirancang pula infografis dengan ukuran A5 $(21 \mathrm{~cm}$ x $14 \mathrm{~cm})$. Infografis merupakan teknik menyajikan informasi secara visual atau grafis sehingga akan lebih mudah dipahami oleh masyarakat (Saptodewo. Infografis ini dimasukkan ke dalam kemasan dan menjadi satu paket dengan masker kain, sehingga diharapkan masyarakat yang mendapatkan paket ini dapat membuka kemasan dan langsung membaca informasi yang ada di dalam infografis sebelum mengambil masker kain.

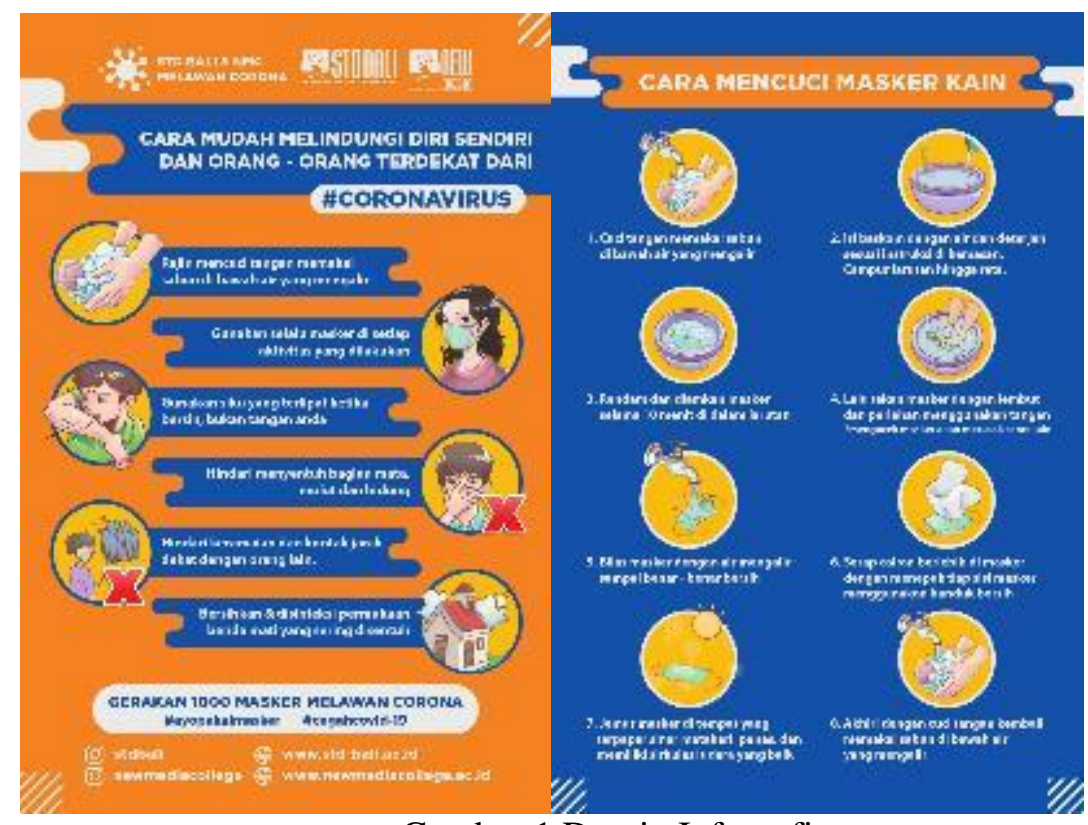

Gambar 1 Desain Infografis

3. Langkah ketiga adalah proses pengemasan masker kain setelah semua masker kain terproduksi, kemasan dan infografis tercetak. Proses pengemasan dilakukan di lab fashion agar keseluruhan items tidak tercecer dan jika ada jumlah yang kurang atau salah dapat dilakukan proses produksi ulang.

4. Langkah keempat, tim yang terdiri dari dosen dan mahasiswa melakukan distribusi masker kain ke Pasar Badung. Tim langsung masuk ke dalam pasar Badung dan memberikan masker kepada pengunjung dan pedagang yang ada di dalam areal pasar. Kegiatan berlangsung dengan baik dan tetap mematuhi protokol Kesehatan dengan tidak membuat kerumunan, dimana civitas akademika langsung mendatangi pedagang dan pengunjung secara acak.

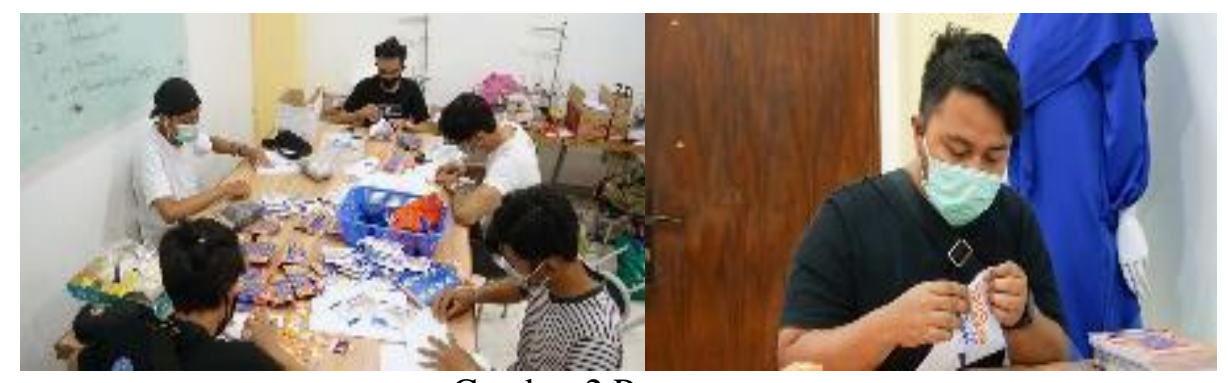

Gambar 2 Proses pengemasan 


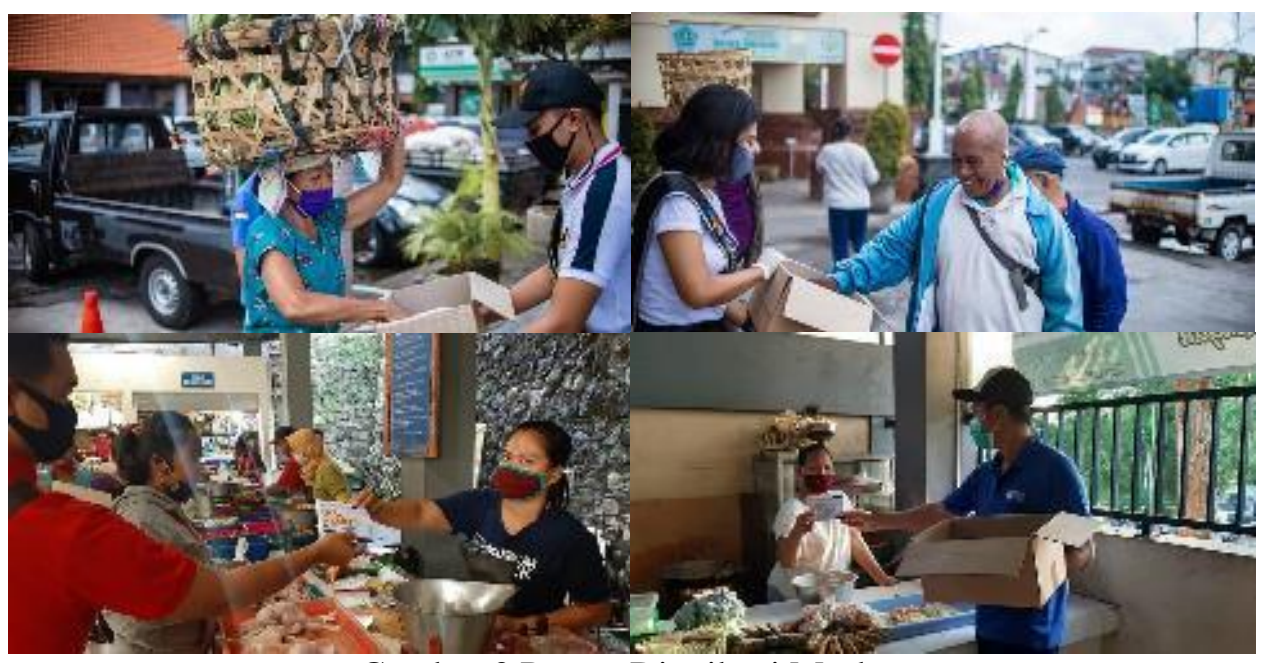

Gambar 3 Proses Distribusi Masker

Hasil pengabdian masyakat mendapat respon positif dari pedagang dan pengunjung Pasar Badung, karena sangat bermanfaat di saat pandemi COVID 19 saat ini. Di saat kondisi masker medis yang langka dan mahal, masker kain menjadi alternatif bagi masyarakat dalam beraktivitas. Namun, masih banyak masyarakat yang menggunakan masker dengan kain yang tipis, menggunakan buff atau menutupi area hidung dan mulut dengan kain seadanya, sehingga pengabdian kepada masyarakat dengan membagikan masker berlapis ini mendapat respon positif.

\section{KESIMPULAN DAN SARAN}

Pengabdian kepada masyarakat pembagian masker kain dan desain infografis ini berjalan dengan lancar dan mendapatkan respon yang positif dari pedagang dan pengunjung Pasar Badung. Hasil yang didapat selama pengabdian masyarakat adalah sebagai berikut:

1. Pemberian masker kain memberikan dampak positif pencegahan penyebaran COVID-19, khususnya pada fasilitas umum yang sering dikunjungi oleh masyarakat, seperti di Pasar Badung, Denpasar yang merupakan pusat kegiatan perekonomian di kota Denpasar.

2. Desain infografis yang memberikan edukasi kepada masyarakat terkait pentingnya mematuhi protokol Kesehatan di saat pandemi COVID 19 dan cara mencuci masker kain, juga menjadi cara efektif dalam memberikan informasi kepada pedagang dan pengunjung di Pasar Badung. Masyarakat menjadi lebih mudah mendapatkan informasi karena diberikan secara langsung.

3. Kegiatan pengabdian kepada masyarakat ini juga meningkatkan rasa sosial civitas akademika Institut Desain dan Bisnis Bali dan dapat mengimplementasikan ilmu yang didapat selama menempuh perkuliahan desain di Institut Desain dan Desain Bali.

4. Kendala selama proses pengabdian masyarakat ini adalah kurangnya jumlah mesin jahit yang dimiliki kampus dan diterapkannya protokol Kesehatan yaitu physical distancing yang menyebabkan beberapa dosen dan mahasiswa harus memproduksi masker kainnya di rumah mereka masing - masing.

\section{Ucapan Terima Kasih}

Penulis mengucapkan terima kasih kepada Lembaga IDB Bali yang telah mensuport kegiatan pengabdian masyarakat, seluruh peserta pengabdian kepada masyarakat baik dari dosen dan mahasiswa Program Studi Desain Komunikasi Visual, Desain Interior dan Desain Mode yang telah berpartisipasi secara aktif di Pengabdian kepada Masyarakat ini. Selain itu penulis juga ingin mengucapkan terima kasih kepada pengelola Pasar Badung kota Denpasar, Pedagang dan Pengunjung Pasar Badung. 


\section{DAFTAR PUSTAKA}

Dinas Pariwisata Denpasar. 2020. Wisata Pasar Tradisional Ubung. https://denpasartourism.com/destination/pasar-badung diakses tanggal 27 November 2020.

Julianti, Sri. 2014. The Art of Packaging. Jakarta : PT. Gramedia Pustaka Utama.

Pane, dr. Merry Dame Cristy. 2020. Virus Corona. https://www.alodokter.com/virus-corona, diakses tanggal 25 November 2020.

Peraturan Gubernur Bali. 2020. https://covid19.hukumonline.com/wpcontent/uploads/2020/09/peraturan_gubernur_bali_nomor_46_tahun_2020.pdf diakses tanggal 25 November 2020

Saptodewo, Febrianto. 2014. Desain Infografis Sebagai Penyajian Data Menarik. Jurnal Desain, Vol 1, No 032014 Universitas Indraprasta PGRI Jakarta, https://journal.lppmunindra.ac.id/index.php/Jurnal_Desain/article/view/563

World Health Organization. 2020. Anjuran mengenai penggunaan masker dalam konteks COVID-19. https://www.who.int/docs/default-source/searo/indonesia/covid19/anjuran-mengenaipenggunaan-masker-dalam-konteks-covid-19-june-20.pdf?sfvrsn=d1327a85_2 diakses tanggal 25 November 2020. 